\section{Characterization of the skin mucus in the common octopus Octopus vulgaris (Cuvier) reared paralarvae}

Gianluca Accogli, ${ }^{1}$ Giovanni Scillitani, ${ }^{2}$ Donatella Mentino, ${ }^{2}$ Salvatore Desantis ${ }^{1}$

${ }^{1}$ Department of Emergency and Organ

Transplants, Section of Veterinary

Clinics and Animal Productions,

University of Bari "Aldo Moro"

${ }^{2}$ Department of Biology, Section of Animal and Environmental Biology, University of Bari “Aldo Moro", Italy

\section{Abstract}

The Octopus vulgaris farming is impaired by the high mortality of the paralarvae during the first month of life. Several factors have been investigated in this regard, but no data exist on the body surface mucus, which represents the interface with the outside environment. This study included morphometric analysis and glycoconjugates characterization of skin mucus in reared Octopus vulgaris paralarvae during the first month of life. Four types of mucous cells were distinguished: mucous $1(\mathrm{~m} 1)$ and mucous $2(\mathrm{~m} 2)$ cells were scattered in the mantle epidermis, mucous $3(\mathrm{~m} 3)$ and mucous $4(\mathrm{~m} 4)$ in the epithelium surrounding the sucker. Except for the presence of fucosylated and neutral glycoconjugates in all mucous cells, each cell type expressed a characteristic glycopattern. $\mathrm{m} 2$ and $\mathrm{m} 4$ contained also suphate and acid non-sulphate glycans, m3 lacked sulphate glycoproteins. Lectin histochemistry showed that mantle mucous cells $(\mathrm{m} 1, \mathrm{~m} 2)$ expressed GlcNAc and lactosamine terminating glycans. $\mathrm{m} 2$ also contained GalNAc terminal or penultimate to sialic acid. $\mathrm{m} 3$ was distinguished by mannosylated glycans terminating with lactosamine and $\mathrm{m} 4$ by $\alpha 2,6$ sialoglycans. Glycoproteins terminating with lactosamine, Gal $\beta 1,3 \mathrm{GalNAc}$, and $\alpha 1,6$-linked fucose were a common feature of paralarvae surface layer. Morphometry revealed a significant decrease of $\mathrm{m} 1$ and $\mathrm{m} 2$ abundance during the first month of life, afterwards the reared paralarvae died. Since the glycopattern did not change during the investigated period, the mantle mucous cells abundance could be related to the Octopus vulgaris paralarvae survival.

\section{Introduction}

The cephalopod Octopus vulgaris is an important candidate for aquaculture although the farming is impaired due to the high mortality of the small planktonic hatchling, ${ }^{1}$ conventionally called paralarvae. ${ }^{2}$ Several authors have suggested that the transition from yolk utilization to active predation is a critical period in the early life history of cephalopods due to low rates of survival. ${ }^{3-5}$ The high mortality problem has been related to the diet and its nutritional content. A nutritional imbalance in the proteins, lipids, minerals and other nutrients of the artificial feed has been pointed as one of the reasons for this high mortality. ${ }^{6}$ Several factors have been investigated about the paralarvae survival such as swimming and feeding behaviour, ontogenetic changes in size and shape, arm growth, water circulation, den availability, food type. ${ }^{1,6-9}$

The skin of cephalopods is a complex system involved in a number of functions, such as lubrication, protection against mechanical damage, microbes, viruses, or proteolytic degradation, osmotic and ionic regulation, oxygen and nutrient uptake, sensitivity, camouflage and communication. ${ }^{6,10,11}$ As in other aquatic organisms, several of these functions are mediated by glycoproteins constituting the mucus, a gellike and viscous substance, secreted by mucous cells. ${ }^{12-14}$ Among the species belonging to phylum Mollusca, the mucus has been extensively studied in gastropods and bivalves. ${ }^{15-18}$ Concerning the cephalopods, mucus secreting cells have been observed in the skin of adults. ${ }^{10,19-21}$ However, skin morphological changes have been described for chromatophores, photophores and Kölliker's organ during the growth of the cephalopods paralarvae and in particular in the genus Octopus. ${ }^{5,10,22,23}$ Thus, despite the epidermis represents the outermost tissue directly interacting with environment and the first line of body defense, to date nothing is known about its mucus content along the O. vulgaris paralarva body, including the suckers. These structures play a key role in a variety of crucial processes for the paralarvae survival such as the grasping, manipulating and investigating objects and suction process. ${ }^{6}$

This study dealt with the morphological features and the glycoconjugate patterns of the skin from reared $O$. vulgaris paralarvae, in order to provide new insights about this critical period of the early life of this species.
Correspondence: Salvatore Desantis, Department of Emergency and Organ Transplants, Section of Veterinary Clinics and Animal Productions, University of Bari "Aldo Moro”, S.P. Casamassima Km. 3, 70010 Valenzano (BA), Italy.

Tel./Fax: +39.080.5443801

E-mail: salvatore.desantis@uniba.it

Key words: Cephalopods; aquaculture; glycoproteins; histochemistry; lectins; skin.

Contributions: GA, SD, conception and design; DM, GA, GS, experiments performing and data analysis; GA, GS, SD, interpretation of data; GA, GS, SD, article drafting. All authors have edited, read and approved the final manuscript.

Acknowledgments: we wish to thank Maricoltura Mattinatese (Mattinata, FG, Italy) in partnership with Acquacoltura Jonica (TA, Italy) for the $O$. vulgaris breeding and the technical support. This research was supported by grants from the Fondo Europeo per la Pesca (F.E.P.) 2007-2013 - Reg. CE n. 1198/2006 - "Reproduction and breeding of the common octopus, Octopus vulgaris".

Conflict of interest: No potential conflict of interest was reported by the authors.

Received for publication: 30 May 2017. Accepted for publication: 28 July 2017.

This work is licensed under a Creative Commons Attribution-NonCommercial 4.0 International License (CC BY-NC 4.0).

(C) Copyright G. Accogli et al., 2017

Licensee PAGEPress, Italy

European Journal of Histochemistry 2017; 61:2518 doi:10.4081/ejh.2017.2518

\section{Materials and Methods}

\section{Animals}

Paralarvae of Octopus vulgaris from Maricoltura Mattinatese (Mattinata, FG, Italy) in partnership with Acquacoltura Jonica (San Vito, TA, Italy) were collected during aquaculture trials financially supported by F.E.P. 2007-2013 - Reg. CE n. 1198/2006 - "Reproduction and breeding of the common octopus, Octopus vulgaris". Mated $O$. vulgaris females $(\mathrm{n}=12)$ were kept in captivity using the technology described by Moxica et al. ${ }^{24}$ and a mean of three hundred thousand paralarvae were obtained from spontaneous spawning. All the paralarvae were kept in captivity according to Iglesias et al. ${ }^{1}$ Briefly, about two thousands of recently hatched (day 0 ) paralarvae were transferred to a $1 \mathrm{~m}^{3} \mathrm{PVC}$ 
circular tank (120 cm of diameter) provided with filtered seawater $(1 \mu \mathrm{m})$ at a concentration of 2 individuals $\mathrm{L}^{-1}$ with black wall and white bottom. Mean water temperature was $22.5^{\circ} \mathrm{C}\left(19.6-22.9^{\circ} \mathrm{C}\right)$, salinity 35 (34.235.7 ) and a $24 \mathrm{~h}$ light cycle was provided with two $36 \mathrm{~W}$ daylight fluorescent tubes, resulting in an intensity of 600-1000 lux on surface. Levels of dissolved oxygen, nitrites and ammonium were measured daily. All tanks were provided of a close water circuit with central aeration during the first week and microalgae (Chlorella sp., Isochrysis galbana and Chaetoceros sp.) were added daily in order to feed the remaining preys in the culture tank, to keep them in the best nutritional condition. Then, the water system was partially open $\left(10 \mathrm{~L} \mathrm{~min}^{-1}\right) 4 \mathrm{~h}$ per day, with a central outlet provided with a $300 \mu \mathrm{m}$ filter. The tank bottom was cleaned by siphoning every 3 days. Paralarvae diet consisted of adult Artemia (1-4 mm TL and 0.05-0.1 individuals $\mathrm{mL}^{-1}$ ) cultivated at $25^{\circ} \mathrm{C}$ during a week with a commercial Selco liquid HUFA (Inve Technologies, Dendermonde, Belgium) and enriched for $24 \mathrm{~h}$ with Chlorella sp.

\section{Sampling and histology processing}

Fifty paralarvae were collected from June to August 2013 at 1-4, 11-14 and 21-28 days after hatching and labelled as P01, P02 and P03, respectively. According to guidelines of European Directive 201/63/UE concerning the humane killing of animals in research and to Villanueva and Norman, ${ }^{6}$ after collection the paralarvae were anesthetized in a $2 \%$ ethanol-seawater and fixed in $4 \%(\mathrm{v} / \mathrm{v})$ PBS-buffered paraformaldehyde for $24 \mathrm{~h}$ at $4^{\circ} \mathrm{C}$. Then the samples were dehydrated through a graded alcohol series and embedded in paraffin wax. Serial sec- tions ( $4 \mu \mathrm{m}$ thick) were cut and, after dewaxing with xylene and hydration in an ethanol series of descending concentrations, were stained with Hematoxylin-Eosin for morphological and morphometric studies and, by means of conventional histochemical procedures or lectin histochemistry for glicoconjugate characterization.

\section{Conventional histochemistry}

For the general staining of carbohydrates Periodic acid-Schiff (PAS) was performed. ${ }^{25}$ Acidic glycans were detected with Alcian Blue pH 2.5 (AB pH 2.5). ${ }^{26}$ Combined High iron diamine-Alcian Blue $\mathrm{pH} 2.5$ (HID-AB pH 2.5) was used to stain simultaneously sulphated. (brown-black) and non-sulphated. (blue) acidic glycans. ${ }^{27}$ Nuclei stained with Mayer's Hematoxylin. Details were about histochemical techniques can be found in Scillitani et al. ${ }^{28}$ All the chemicals were from Sigma-Aldrich (St. Louis, MO, USA).

\section{Lectin histochemistry}

Binding of ten FITC-labelled lectins (Vector Laboratories, Burlingame, CA, USA) was tested to investigate the composition and distribution of oligosaccharidic chains in mucins (Table 1 and references therein $\left.{ }^{29-38}\right)$. Sections were incubated for $1 \mathrm{~h}$ at room temperature with the lectin solution in HEPES and subsequently rinsed in the same buffer and mounted in Fluoromount (Sigma-Aldrich). Each experiment was repeated twice on each sample.

Controls for lectin labelling were performed by i) substitution of lectin with HEPES alone; ii) incubation in lectin with inhibitory sugar added $(0.2-0.5 \mathrm{M})$; iii) binding to the egg envelope of the toads Bombina pachypus and Bufo bufo, the mucins of which are demonstrated to be labelled by the tested lectins. ${ }^{39,40}$

Lectin-binding was observed in epifluorescence under $495 \mathrm{~nm}$ light emission. Photos were taken by a Nikon DMX 1200 camera coupled with a Nikon Eclipse 600 photomicroscope (Nikon Instruments SpA, Calenzano, FI, Italy).

\section{Morphometry and statistical analysis}

Four types of PAS positive muciparous cells (two in the mantle skin and two in the arms skin) were detected during the investigated periods (P01, P02, P03). The number of each muciparous cell type was counted on 30 microphotograph fields randomly detected in PAS-Hematoxylin stained sections using a $60 \mathrm{x}$ lens, and the cell abundance was expressed as mean numbers of mantle muciparous cells/100 $\mu \mathrm{m}$ and as number of mucous cells per sucker.

Image analysis was performed by ImageJ software. ${ }^{41}$ Statistical evaluations were performed separately for each cell type. Descriptive statistics (arithmetic mean, standard deviation, sample variance, standard error, kurtosis, skewness) were computed for each sample. The normality of sample distributions was tested by Shapiro-Wilk tests and the homogeneity of sample variances were tested by Levene's tests. The significance of variation among mean values was evaluated by both parametric one-way Analysis of Variance (ANOVA) and non-parametric KruskalWallis test (KW). Post-hoc pairwise comparisons allowed to detect the pairs of sample values which differed significantly and were performed with both parametric Tukey's Honestly-Significant-Difference (THSD, related to ANOVA) and non-parametric Dwass-Steel-Chritchlow-Fligner

Table 1. Lectin used, their sugar specificities and the inhibitory sugars used in control experiments.

\begin{tabular}{|c|c|c|c|c|}
\hline $\begin{array}{l}\text { Lectin } \\
\text { abbreviation }\end{array}$ & Source of lectin & Binding specificity & $\mu \mathrm{g} / \mathrm{mL}$ & $\begin{array}{l}\text { Inhibitory sugar } \\
\text { concentration }\end{array}$ \\
\hline WGA & Triticum vulgaris ${ }^{29}$ & $(\mathrm{GlcNAc} \beta 1,4) n$ & 20 & $0.5 \mathrm{M} \mathrm{GlcNac}$ \\
\hline GSA II & Griffonia simplicifolia ${ }^{30}$ & GlcNAc & 10 & $0.5 \mathrm{M} \mathrm{GlcNac}$ \\
\hline SNA & Sambucus nigra ${ }^{31}$ & Neu5Aca2,6Gal/GalNAc & 20 & $0.2 \mathrm{M} \mathrm{Neu} 5 \mathrm{Ac}$ \\
\hline PNA & Arachis hypogaea ${ }^{32}$ & Gal $\beta 1,3 \mathrm{GalNAc}$ & 10 & $0.2 \mathrm{M} \mathrm{Gal}$ \\
\hline RCA I & Ricinus communis $^{33}$ & Gal $\beta 1,4 \mathrm{GlcNAc}$ & 20 & $0.2 \mathrm{M} \mathrm{Gal}$ \\
\hline SBA & Glycine $\max ^{34}$ & GalNAc & 20 & $0.2 \mathrm{M}$ GalNAc \\
\hline Con A & Canavalia ensiformis $^{35}$ & D-Man, D-Glc & 20 & $0.1 \mathrm{M} \mathrm{M} \alpha \mathrm{M}$ \\
\hline AAA & Aleuria aurantia ${ }^{36}$ & Fuc $\alpha 1,6 \mathrm{GlcNAc}-\beta N A s n ;$ Fuc $\alpha 1,3$, Fuc $\alpha 1,4$ & 10 & $0.2 \mathrm{M} \mathrm{L}$-Fuc \\
\hline UEAI & Ulex europaeus ${ }^{37}$ & Fuc $\alpha 1,2$ & 10 & $0.2 \mathrm{M} \mathrm{L-Fuc}$ \\
\hline LTA & Tetragonolobus purpureus ${ }^{38}$ & L-Fuc $\alpha 1,6 \mathrm{GlcNAc} ;$ L-Fuc $\alpha 1,2 \mathrm{Gal} \beta 1,4[\mathrm{~L}-\mathrm{Fucl}, 3]$ GlcNAc $\beta 1,6 \mathrm{R}$ & 20 & $0.2 \mathrm{M} \mathrm{L-FuC}$ \\
\hline
\end{tabular}

Asn, asparagine; Fuc, fucose; Gal, galactose; GalNAc, N-acetylgalactosamine; Glc, glucose; GlcNAc, N-acetylglucosamine; M $\alpha$ M, methyl- $\alpha$-mannopyranoside; Man, mannose; Neu5Ac, N-acetylneuraminic (sialic) acid. 
(DSCF, related to Kruskal-Wallis) tests. Significance for probability computed from tests was set at $\mathrm{P}<0.01$. Statistical computations were generated by the Real Statistics Resource Pack software release 4.3. ${ }^{42}$ All data were expressed as means \pm standard error (SE).

\section{Results}

\section{Morphology}

The gross outer morphology of $O$. vulgaris paralarvae displayed relatively short arms, a large buccal mass, two large eyes and several chromatophores distributed in the skin covering the mantle and arms (Figure 1A).

The epidermis covering the mantle of paralarvae showed a simple columnar epithelium constituted by epitheliocytes and mucous cells (Figure 1B). The epidermis was crossed by several Kölliker's organs (Figure 1B). The head portion of paralarva body contained well developed and differentiated arms. The ventral side of each arm showed at least three suckers which were constituted by two "chambers": the infundibulum and the acetabulum (Figure 1C). The infundibulum was in the outer part and the acetabulum in the inner part of the sucker (Figure 1C). The infundibulum is the exposed portion of the sucker and the acetabulum is a spheroidal cavity that opens into the infundibulum through an orifice (Figure 1C). The epithelium covering the infundibulum was simple cuboidal, whereas the epithelium lining the acetabulum as well as the space interposed between adjacent suckers had a simple squamous appearance (Figure 1C).

\section{Conventional histochemistry}

The results of histochemistry methods are summarized in Table 2. The epitheliocytes of both the mantle and arms showed no cytoplasmic staining with all the used histochemical methods. As for the skin, api- cal surface it displayed PAS positivity in the mantle and suckers (Figure 2 A,B), whereas it showed $\mathrm{AB} 2.5$ staining in the mantle (Figure 2C) and HID reactivity in the cuticle of the sucker infundibulum. Four differ- ent types of mucus-containing cells (named $\mathrm{m} 1, \mathrm{~m} 2, \mathrm{~m} 3, \mathrm{~m} 4)$ were distinguishable based on their appearance, localization and histochemical reactivity (Figure 2, Table 2). $\mathrm{m} 1$ and $\mathrm{m} 2$ cells showed columnar shape

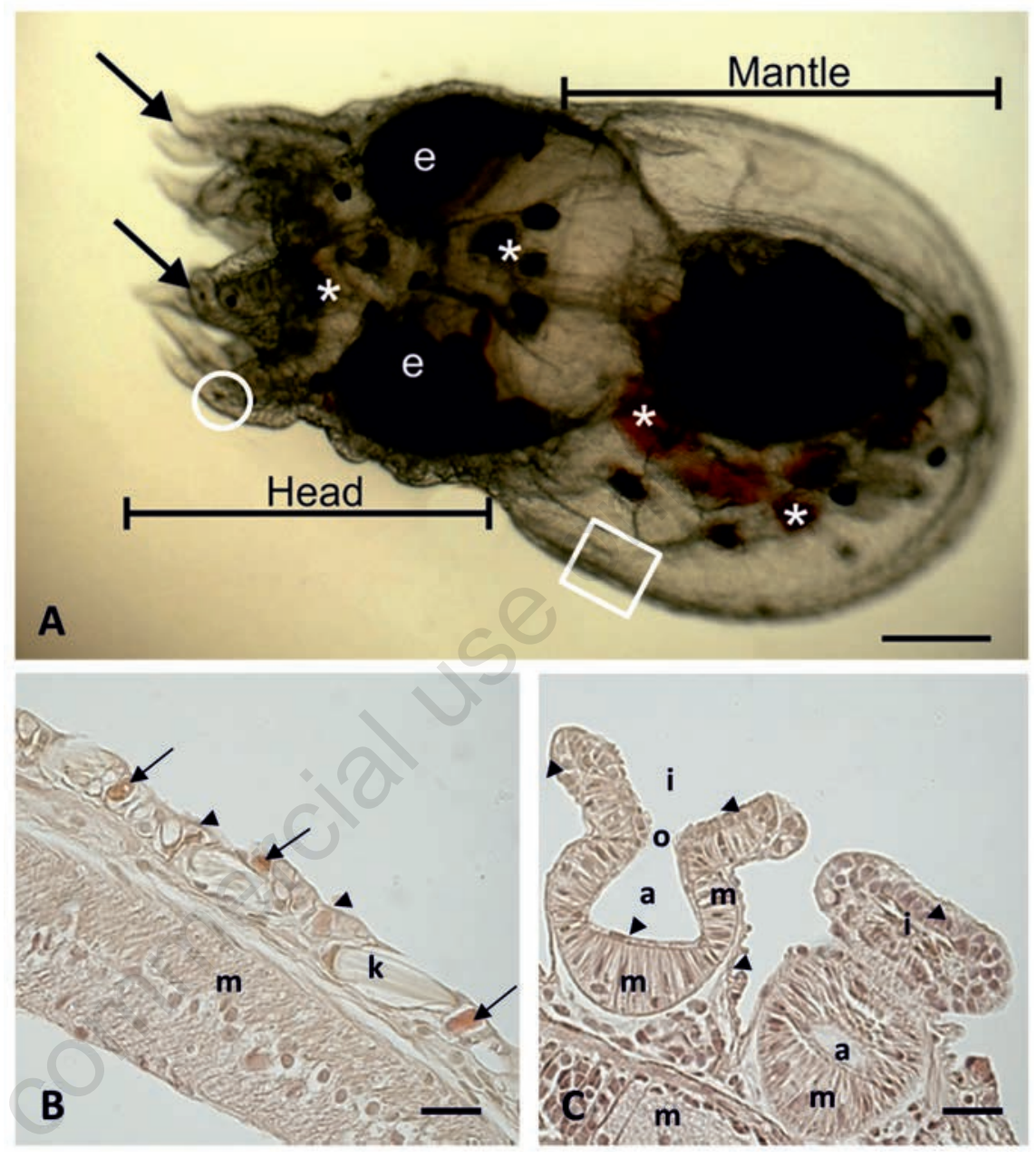

Figure 1. Gross morphology of a 2 days-old Octopus vulgaris paralarva (A) and (B,C) histological sections from squared and circled areas of $A$, respectively. A) Dorsal view of a paralarva showing short arms, two large eyes and several chromatophores distributed in the mantle and arms skin. B) Light micrograph of the mantle displaying columnar epitheliocytes and mucous cells scattered in the epidermis, Kölliker's organ organs and muscle wall. C) Light micrograph exhibiting the infundibulum and the acetabulum of two suckers. a, acetabulum; $i$, infundibulum; $k$, Kölliker's organ; m, muscle fibers; $o$, orifice; arrows, arms; arrowhead, epithelium; small arrow, mucous cells; e, eye; *chromatophores. B,C) H\&E staining. Scale bars: A) $0.18 \mathrm{~mm}$; B,C) $20 \mu \mathrm{m}$.

Table 2. Conventional and lectin histochemistry staining pattern of the mantle skin and suckers of the reared Octopus vulgaris paralarvae.

\begin{tabular}{|c|c|c|c|c|c|c|c|c|c|c|c|c|c|}
\hline 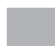 & PAS & AB 2.5 & HID & WGA & GSA II & SNA & PNA & RCA I & SBA & Con A & AAA & UEA I & LTA \\
\hline as & + & $+\mathrm{m}$ & $+\mathrm{i}$ & $+\mathrm{i}$ & - & - & $+\mathrm{m}, \mathrm{i}$ & $+\mathrm{m}, \mathrm{i}$ & - & $+a$ & $+\mathrm{m}, \mathrm{i}$ & $+\mathrm{i}, \mathrm{a}$ & $+\mathrm{i}$ \\
\hline $\mathrm{ml}$ & + & - & - & + & + & - & - & + & - & - & + & + & + \\
\hline $\mathrm{m} 2$ & + & $+^{*}$ & $+^{*}$ & + & + & + & - & + & + & - & + & + & + \\
\hline $\mathrm{m} 3$ & + & + & - & + & - & - & - & + & - & + & + & - & - \\
\hline $\mathrm{m} 4$ & + & + & $+^{*}$ & + & - & + & - & - & - & - & + & - & - \\
\hline
\end{tabular}

a, acetabulum; as, apical surface; i, infundibulum; m, mantle; m1, mucous type 1 cell; m2, mucous type 2 cell; m3, mucous type 3 cell; m4, mucous type 4 cell; *occasional positive cells; -, no staining; +, presence of reactivity. 
and were in the mantle (Figure 2 A,C,E). $\mathrm{m} 1$ cells were coarse-grained PAS positive cells (Figure 2A), whereas $\mathrm{m} 2$ cells were fine-grained cells displaying strong PAS positivity (Figure 2A). Some $\mathrm{m} 2$ cells showed moderate affinity with both $\mathrm{AB} 2.5$ (Figure 2C) and HID (inset of Figure 2E) staining. $\mathrm{m} 3$ and $\mathrm{m} 4$ cells were found in the epithelium surrounding the suckers. m3 cells were roundish in shape and were scattered in the epithelium surrounding the infundibulum (Figure 2 B,D,F) and strongly stained with PAS (Figure 2B) and AB 2.5 (Figure 2 D,F). m4 were round cells scattered in the epithelium surrounding the acetabulum zone of the sucker (Figure 2B, D,F). They displayed PAS (Figure 2B) and $A B$ 2.5 (Figure 2D) positivity, although some of them exhibited HID positivity (Figure 2F). No staining variation was detected in the mantle and arm structures during the investigated periods. Kölliker's organs showed weak staining with the used methods (Figure 2 A,C,E).

\section{Lectin histochemistry}

The results of lectin histochemistry are summarized in Table 2 and illustrated in Figures 3 and 4.

\section{$N$-acetylglucosamine residues (WGA, GSA II)}

WGA bound to all the mucous cell types (Figure $3 \mathrm{~A}, \mathrm{~B}$ ) as well as to the cuticle of the sucker infundibulum (Figure 3B). GSA II reacted with the $\mathrm{m} 1$ and $\mathrm{m} 2$ cells of the mantle (Figure 3C), whereas did not react with the mucosal cells and epithelium lining the arms (Figure 3D).

\section{Sialic acid residues (SNA)}

SNA, specific for NeuNAc 22,6 Gal/GalNAc terminal residues, linked the $\mathrm{m} 2$ and $\mathrm{m} 4$ cells but not the other mucous cells and the mantle and arms surface (Figure 3E, F).

\section{Terminal galactose residues (PNA and RCA I)}

PNA reacted with the apical surface of the epitheliocytes lining the mantle (Figure $3 \mathrm{G})$ and with the cuticle of sucker infundibulum (Figure 3H). This lectin did not reveal binding sites in any mucous cells. RCA I bound $\mathrm{m} 1$ and $\mathrm{m} 2$ cells in the mantle (Figure 3I), $\mathrm{m} 3$ cells in the arms (Figure 3J) as well as the mantle surface and the cuticle lining the sucker infundibulum (Figure $3 \mathrm{~K}$ ).

\section{$N$-acetylgalactosamine residues (SBA)}

SBA displayed binding sites in $\mathrm{m} 2$ cells of the mantle (Figure 3L) and no reactivity in the arms (Figure 3M).

\section{Terminal/internal mannose/glucose residues (Con $A)$}

Con A did not bind the mantle whereas revealed high mannose glycans in the arms at level of the $\mathrm{m} 3$ cells and the cuticle of sucker acetabulum (Figure 4A).

\section{Terminal fucose residues (AAA, UEA I, LTA)}

AAA linked to all mucous cell types as well as to the surface of the mantle and sucker infundibulum (Figure 4 B,C). UEA I bound the $\mathrm{m} 1$ and $\mathrm{m} 2$ cells (Figure 4D) as well as the internal surface of the sucker (Figure 4E). LTA showed a similar binding pattern except for the lack of reactivity in the sucker acetabulum (Figure 4F).

The lectin histochemistry reactions did not change during the investigated periods and they were considered reliable because the negative-control procedures gave no reactivity (Figure 4G).
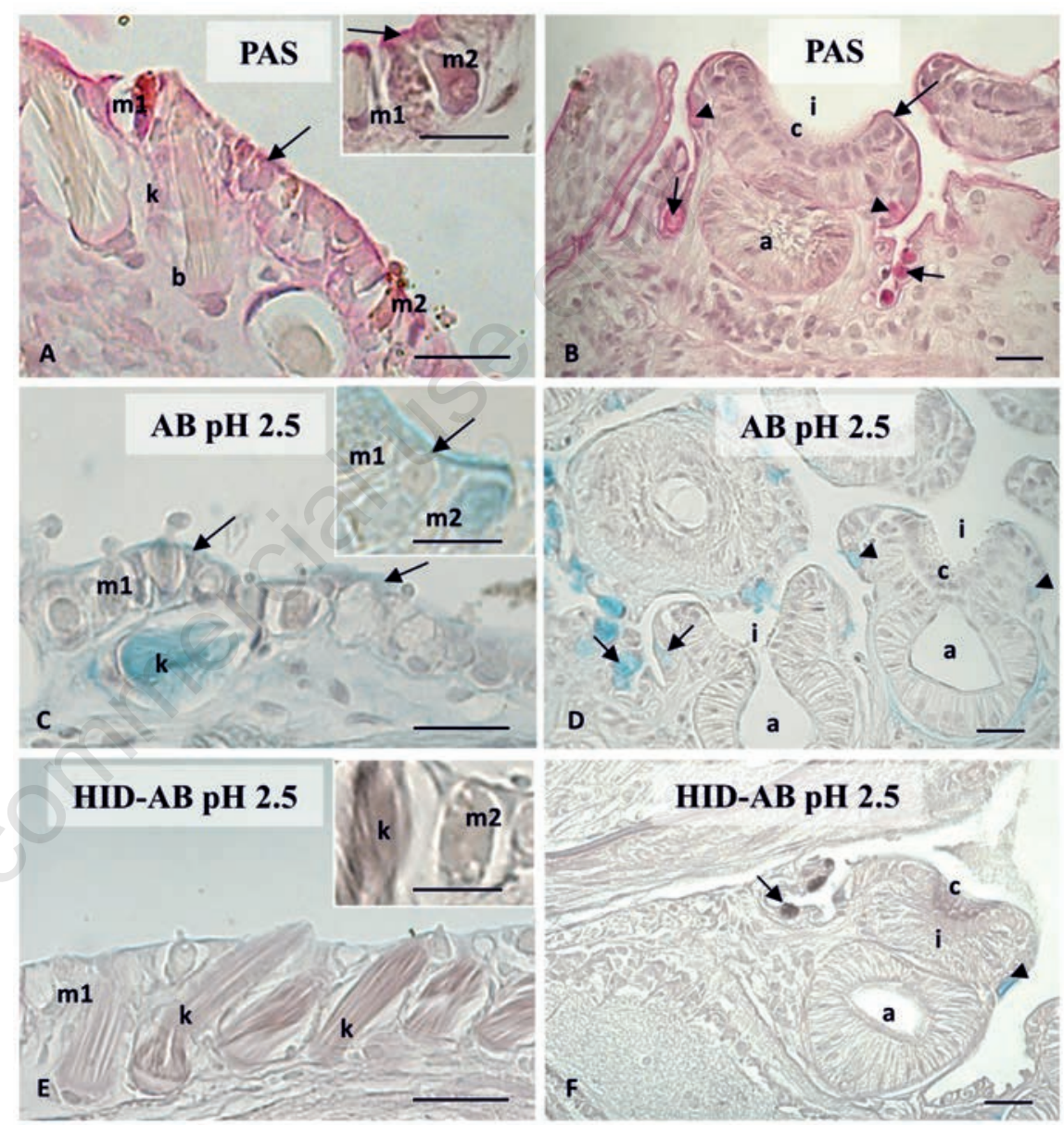

Figure 2. Skin of Octopus vulgaris paralarvae stained with PAS (A,B), Alcian Blue pH 2.5 (AB 2.5) (C,D) and HID-AB 2.5 (E,F) methods. A) PAS staining of a P01 paralarva mantle showing positivity of the $\mathrm{m} 1$ and $\mathrm{m} 2$ cells and the apical surface of epidermis (large arrow); inset: detail of coarse- and fine-grained granules in $\mathrm{m} 1$ and $\mathrm{m} 2$ cells, respectively. B) PAS positivity of $\mathrm{m} 3$ cells (arrowhead), $\mathrm{m} 4$ cells (small arrow), and the apical surface of arm epidermis (large arrow) and the cuticle (c) of a P02 paralarva sucker. C) AB2.5 staining of the mantle from a P02 paralarva showing positivity of the epidermis surface (large arrow) and Kölliker's organ fibers (k); $\mathrm{m} 1$ and $\mathrm{m} 2$ cells were usually unstained although $\mathrm{m} 2$ cells were occasionally stained (inset). D) AB 2.5 positivity of $\mathrm{m} 3$ (arrowhead) and m4 (small arrow) cells in P03 paralarva arms. E) HID-AB2.5 procedure displaying HID positivity (brown staining) of the Kölliker's organ organ fibers (k) and occasional $\mathrm{m} 2$ cells (inset) (P03 paralarva mantle). F) HID-AB 2.5 procedure showing rare HID (brown staining) m4 cells (small arrow) and AB 2.5 (blue staining) m3 cells (arrowhead) (P02 paralarva arm). A, acetabulum; c, cuticle; I, infundibulum; k, Kölliker's organ fibers; large arrow, epithelial apical surface; $\mathrm{m} 1$, coarse-grained mucous cell; $\mathrm{m} 2$, finegrained mucous cell; arrowhead, $\mathrm{m} 3$ cell; P01, P02, P03, 1-4, 11-14 and 21-28 days after hatching samples; small arrow, m4 cell. Scale bars: A-F) $20 \mu \mathrm{m}$; insets in A,C,E) $10 \mu \mathrm{m}$. 


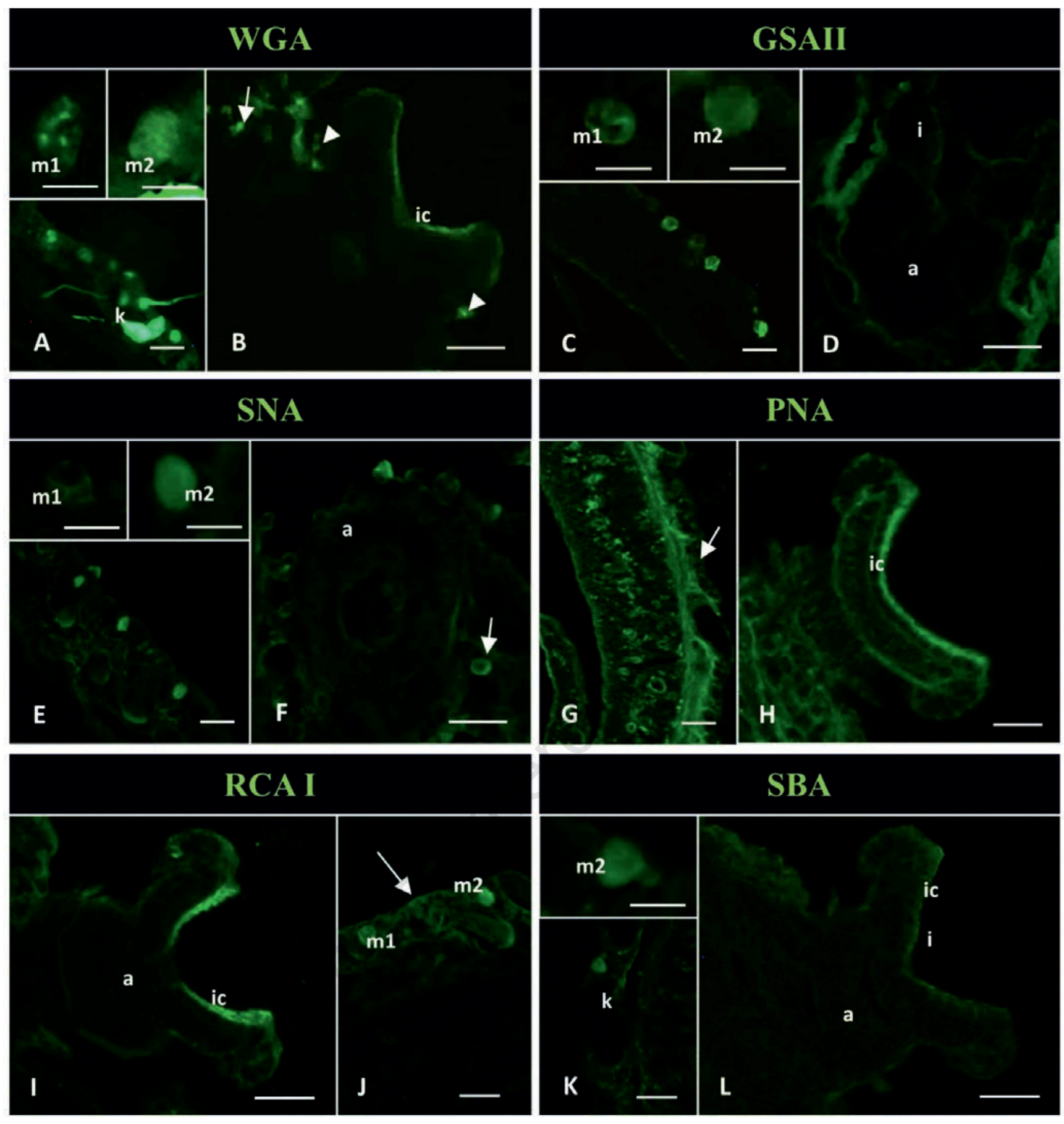

Figure 3. Lectin histochemistry of Octopus vulgaris paralarvae. A) WGA binding sites in m1, m2, Kölliker's organ of the mantle from a P01 paralarva. B) WGA reactivity in the infundibulum cuticle, $\mathrm{m} 3$ and $\mathrm{m} 4$ cells of a P01 paralarva sucker. C) GSA II staining of $\mathrm{m} 1$ and $\mathrm{m} 2$ cells from a P02 paralarva. D) GSA II negativity with sucker from same paralarva of C. E) SNA binding sites in m2 but not $\mathrm{m} 1$ cells from mantle of a P01 paralarva. F) SNA reactivity of $\mathrm{m} 4$ cells in same paralarva of E. G, PNA staining of mantle surface of a P03 paralarva. H, PNA affinity with the infundibulum cuticle of a P03 paralarva. I) RCA I staining of mucous cells and surface lining the mantle of a P01 paralarva. J) RCA I binding sites in $\mathrm{m} 3$ and infundibulum cuticle of a sucker from same paralarva of I. K) SBA binding with $\mathrm{m} 1$ cells of P01 paralarva mantle. L) SBA did not react with arms of the same paralarva of $K$. a, acetabulum; arrowhead, m3 cell; i, infundibulum; ic, infundibulum cuticle; $k$, Kölliker's organ; $m 1$, coarse-grained mucous cell; $\mathbf{m} 2$, fine-grained mucous cell; P01, P02, P03, 1-4, 11-14 and 21-28 days after hatching samples; large arrow, mantle apical surface; small arrow, m4 cell. Scale bars: A-L) $20 \mu \mathrm{m}$; insets in A,C,E,K) $10 \mu \mathrm{m}$. 


\section{Statistical analysis}

Descriptive statistical analysis was performed on the abundance of PAS-reactive $\mathrm{m} 1, \mathrm{~m} 2, \mathrm{~m} 3$ and $\mathrm{m} 4$ cell types and values obtained (expressed as M1, M2, M3 and M4, respectively) are showed in Tables 3 and 4 . Figure 5 shows the histograms comparing mean values and standard errors for M1-M4 in the three samples. M1 and M2 are significantly different among samples. The M1 increases from P01 to P02 but decreases again in $\mathrm{P} 03$, whereas M2 decreases from $\mathrm{P} 01$ to $\mathrm{P} 03$. The relative abundance of the two cell types indicates that in P01 sample M2 outnumbers M1, but they attain similar values in P02 and P03. The deviations from normality tested by Shapiro-Wilk tests (not shown) were not significant except for M2 in P02
( $\mathrm{W}=0.7994, \mathrm{P}=0.0006$ ). Homogeneity of variances, assessed by Levene's tests (not shown), was revealed in M1 but not in M2 $(\mathrm{P}=0.0034)$. One-Way ANOVA and Shapiro-Wilk tests were performed on both M1 and M2 values among the samples and all the results are resumed in Table 5. Both tests revealed a high significant difference between M1 and M2 means among samples. The results of post-hoc comparisons of means between samples by THSD and DSCF tests are in Table 6. Most pairwise comparisons indicate significant differences, except for P01-P03 (THSD only) and P02-P03 (both THSD and DSCF).

The abundance of $\mathrm{m} 3$ e $\mathrm{m} 4$ sucker cells (indicated as M3 and M4, respectively) did not show deviations from normality tested by Shapiro-Wilk tests (not shown) and their variances had homogeneous values by
Levene's tests (not shown). The mean values did not vary significantly among samples (Figure 5 and Table 4). Thus, post-hoc comparisons were not performed.

\section{Discussion}

The body surface of aquatic organisms is covered with a protective mucous layer which represents the first interface between the animal and the environment. Therefore, the evaluation of the glycoconjugates composition of the skin mucus could give new data about the biology of octopus paralarvae which, due to high mortality rate, represent an impairment for the aquaculture. In this study, for the first time, we describe the glycan profile of the epidermis and suckers
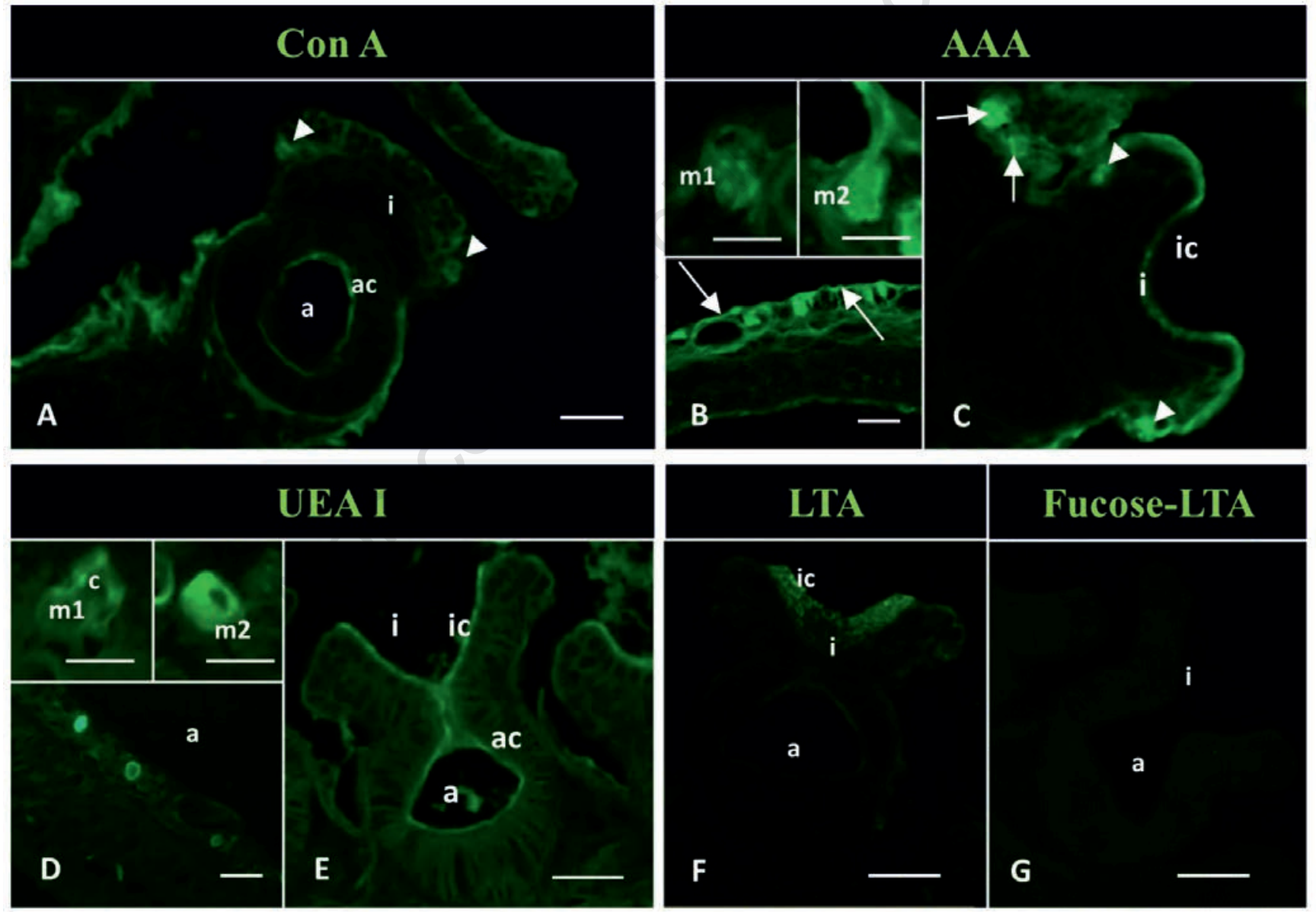

Figure 4. Lectin histochemistry of Octopus vulgaris paralarvae. A) Con A reactivity with $\mathrm{m} 3$ cells and acetabulum cuticle from a P01 paralarva. B) AAA staining of surface and $\mathrm{m} 1$ and $\mathrm{m} 2$ cells in P02 paralarva mantle. C) AAA binding with $\mathrm{m} 3$ and $\mathrm{m} 4$ cells and infundibulum cuticle of same paralarva of B. D) UEA I reactivity with the mucous cells of a P03 paralarva mantle. E) UEA I affinity with the infundibulum and the acetabulum cuticle of a P03 paralarva. F) LTA binding sites in the infundibulum cuticle of a P03 paralarva sucker. G) LTA un-reactivity with the P03 paralarva sucker when the inhibitory sugar was added (negative control). a, acetabulum; i, infundibulum; ac, acetabulum cuticle; ic, infundibulum cuticle; m1, coarse-grained mucous cell; m2, fine-grained mucous cell; arrowhead, m3 cell; large arrow, mantle apical surface; small arrow, m4 cell; P01, P02, P03, 1-4, 11-14 and 21-28 days after hatching samples. Scale bars: A-G) $20 \mu \mathrm{m}$; insets in B and D) $10 \mu \mathrm{m}$. 
in the reared $O$. vulgaris paralarvae.

The cephalopod epidermal mucussecreting cells have received little attention compared to other mollusks. ${ }^{18}$ However, the diversity of mucous cells types found in the studied cephalopod species, ${ }^{10,21}$ and the presence of a thin mucus-gel film surrounding the animal body ${ }^{6}$ underlines its importance in the post-hatchling life. ${ }^{43}$

Morphological investigations revealed that the mantle was lined with the epidermis, which was a simple columnar epithelium constituted of epitheliocytes and two different types of mucous secreting cells: $\mathrm{m} 1$ and $\mathrm{m} 2$ cells. Both these secretory cells contained neutral glycoproteins (PAS staining) which presumably ended with GlcNAc (WGA and GSA II reactivity), lactosamine (RCA I affinity), and fucose (AAA, UEAI, and LTA binding). However, these two cell types produced different glycans since $\mathrm{m} 2$ cells synthesized also carboxyl (AB 2.5 positivity) and/or O-sulphate esters (HID staining) glycoproteins containing GalNAc and sialic acid (SBA and SNA binding, respectively).

This different glycosylation pattern could be related to differential functions of the mucins secreted by $\mathrm{m} 1$ and $\mathrm{m} 2$ cells. Interestingly, GalNAc is important for the O-glycosidic linkage of the saccharidic chains to the protein backbone (typical to secreted mucins ${ }^{44}$ ) and is often subterminal to sulphated and carboxylated residuals. ${ }^{45,46}$ Concerning sialic acid, this sugar contributes to the net negative charge of glycans because it is typically found at the terminal position of glycans and it is involved in several important functions, such as intercellular interactions, transport of ions and molecules, viscosity of mucus, protec-
Table 3. Descriptive statistics for M1 and M2 numbers of mucous cells per $100 \mu \mathrm{m}$ in the Octopus vulgaris paralarvae mantle skin.

\begin{tabular}{lcccccc} 
Statistics & \multicolumn{2}{c}{ P01 } & \multicolumn{2}{c}{ P02 } & \multicolumn{2}{c}{ P03 } \\
Number of sections & 46 & 46 & 21 & 21 & 21 & 21 \\
Mean & 1.002 & 2.860 & 1.422 & 1.359 & 0.969 & 0.836 \\
\hline Maximum & 1.554 & 4.533 & 2.214 & 2.792 & 2.134 & 1.469 \\
Minimum & 0.484 & 1.062 & 0.899 & 0.731 & 0.268 & 0.429 \\
\hline Range & 1.070 & 3.471 & 1.315 & 2.062 & 1.866 & 1.039 \\
Standard deviation & 0.253 & 0.834 & 0.324 & 0.508 & 0.510 & 0.242 \\
\hline Sample variance & 0.064 & 0.691 & 0.105 & 0.258 & 0.260 & 0.058 \\
Standard error & 0.037 & 0.123 & 0.071 & 0.111 & 0.111 & 0.053 \\
\hline Kurtosis & -0.292 & -0.512 & 0.727 & 2.910 & -0.371 & 1.410 \\
Skewness & 0.175 & 0.239 & 0.848 & 1.764 & 0.573 & 0.971 \\
\hline Rank sum & 1911 & 2931 & 1466 & 605 & 539 & 380 \\
\hline
\end{tabular}

Table 4. Descriptive statistics for M3 and M4 numbers of sucker mucous cells in the paralarvae of Octopus vulgaris.

\begin{tabular}{lcccccc} 
Statistics & M3 & M4 & M3 & M4 & M3 & P03 \\
Number of suckers & 24 & 24 & 28 & 28 & 27 & 27 \\
Mean & 11.83 & 10.79 & 11.89 & 11.14 & 10.93 & 10.78 \\
\hline Maximum & 15 & 15 & 15 & 15 & 15 & 15 \\
Minimum & 8 & 8 & 8 & 8 & 8 & 8 \\
\hline Range & 7 & 7 & 7 & 7 & 7 & 7 \\
Standard deviation & 2.73 & 2.25 & 2.23 & 2.30 & 2.15 & 2.38 \\
\hline Sample variance & 7.45 & 5.04 & 4.99 & 5.31 & 4.61 & 5.64 \\
Standard error & 0.56 & 0.46 & 0.42 & 0.44 & 0.41 & 0.46 \\
\hline Kurtosis & -1.60 & -0.58 & -1.17 & -1.25 & -0.86 & -0.93 \\
Skewness & -0.40 & 0.59 & -0.20 & -0.07 & 0.58 & 0.53 \\
\hline Rank sum & 1016.00 & 933.50 & 1213.00 & 1187.50 & 931.00 & 1039.00 \\
\hline
\end{tabular}
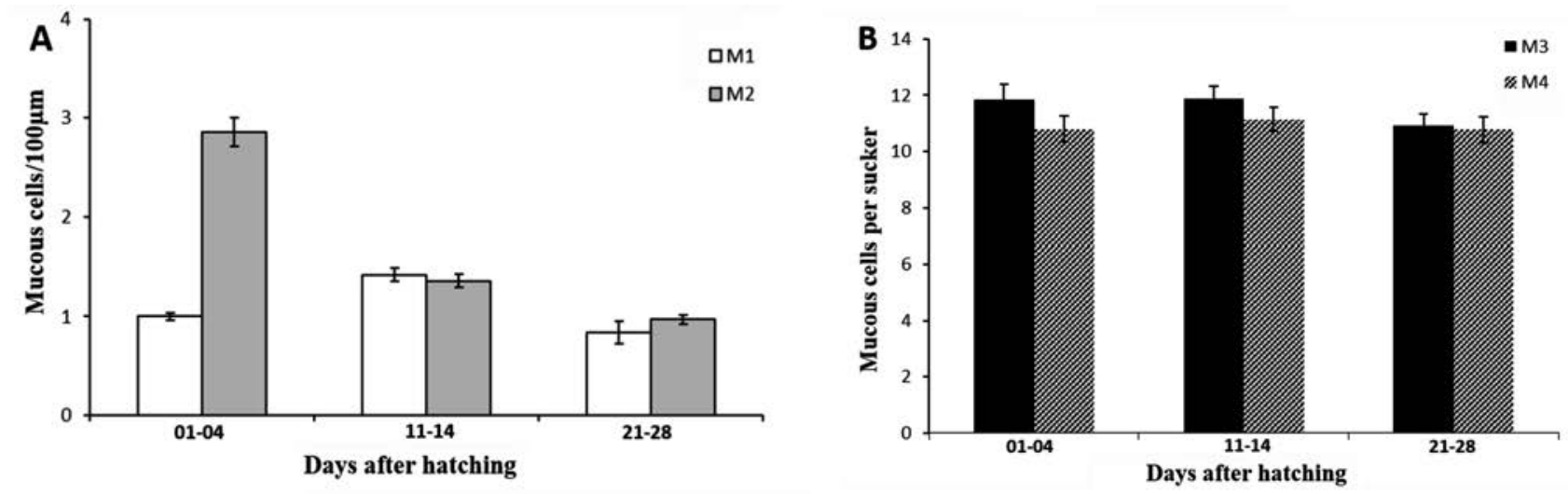

Figure 5. Histograms showing mantle and suckers mucous cells abundance in Octopus vulgaris paralarvae. Values are expressed as mean \pm SE. M1, M2, M3, M4 indicate the abundance of $\mathrm{m} 1, \mathrm{~m} 2, \mathrm{~m} 3$ and $\mathrm{m} 4$ cells, respectively. 
tion from microorganisms or interactions with symbionts, ${ }^{47}$ and its alterations characterize several pathologies in vertebrates including human. ${ }^{48}$ The presence of the sialic acid is an unusual finding in mollusks, where it is usually substituted by muramic acid. $^{45,49}$ Differently from the other monosaccharides, the backbone of this sugar can exhibit pronounced chemical diversity in structure and linkage so that all the known sialic acids constitute the sialome. ${ }^{50}$ Thus, sialome analysis could be a useful tool for monitoring health conditions of paralarvae from hatching to settlement. Furthermore, the sulphated and fucosylated glycoproteins (HID, AAA, UEA I and LTA reactivity) could play an important role in microbial interactions. ${ }^{49}$ A morpho-functional interpretation of our results requires comparison with literature data, but this is difficult because of both the absence of such investigations and the different terminology used in reported studies. ${ }^{10,51}$ Ultrastructural analysis of the $O$. vulgaris epidermis revealed the presence of three type of mantle secretory cells (type 1, 2, and 3) but no data concerning the type of secreted mucosubstances. ${ }^{51}$ In sepiolids, the skin of Euprymna scolopes exhibited two types of secreting cells such as ovate cells and goblet cells producing sulphate and neutral glycoproteins, respectively. ${ }^{19}$ Moreover, in the Sepia esculenta skin $^{21}$ three types of secreting cells (A, B, and C cells) were observed.
All these cells secreted neutral glycoconjugates and type A produced also acidic glycans.

The morphometric analysis showed that the trends of $\mathrm{m} 1$ and $\mathrm{m} 2$ cells number were significantly different, because $\mathrm{ml}$ cells increased during the first two weeks and decreased during the fourth week after hatching, whereas $\mathrm{m} 2$ cells gradually reduced during the first month after hatching. However, interestingly the number of both mucous cell types decreased at the end of the month. This suggests two different hypotheses: i) the mucus secretion at level of the mantle changes at the end of the first month after hatching; ii) the reduction in the number of mucous cells could cause some

Table 5. Results of One-Way ANOVA and Kruskal-Wallis tests for comparisons of means between M1 and M2 numbers of mucous cells per $100 \mu \mathrm{m}$ of the Octopus vulgaris paralarvae mantle skin.

\begin{tabular}{|c|c|c|c|c|c|c|c|}
\hline M1 & Test & & & SS & df & MS & \\
\hline & $\begin{array}{l}\text { One-Way ANOVA } \\
\text { Kruskal-Wallis }\end{array}$ & $\begin{array}{l}\text { Sources } \\
\text { F } \\
\text { P } \\
\text { H } \\
\text { P }\end{array}$ & $\begin{array}{l}\text { Between groups } \\
\text { Within groups } \\
\text { Total }\end{array}$ & $\begin{array}{c}3.9659 \\
6.1505 \\
10.1163\end{array}$ & $\begin{array}{c}2 \\
85 \\
87\end{array}$ & $\begin{array}{l}1.9829 \\
0.0724 \\
0.1163\end{array}$ & $\begin{array}{c}27.4042 \\
0.0000 \\
32.6394 \\
0.0000\end{array}$ \\
\hline M2 & Test & & & SS & df & MS & \\
\hline & $\begin{array}{l}\text { One-Way ANOVA } \\
\text { Kruskal-Wallis }\end{array}$ & $\begin{array}{l}\text { Sources } \\
\text { F } \\
\text { P } \\
\mathrm{H} \\
\mathrm{P}\end{array}$ & $\begin{array}{l}\text { Between groups } \\
\text { Within groups } \\
\text { Total }\end{array}$ & $\begin{array}{c}64.7213 \\
41.4948 \\
106.2161\end{array}$ & $\begin{array}{c}2 \\
85 \\
87\end{array}$ & $\begin{array}{c}32.3607 \\
0.4882 \\
1.2209\end{array}$ & $\begin{array}{c} \\
\\
66.2892 \\
0.0000 \\
56.3832 \\
0.0000\end{array}$ \\
\hline MB & Test & $\theta$ & & SS & df & MS & \\
\hline & Kruskal-Wallis & $\begin{array}{l}\text { Sources } \\
\text { F } \\
\text { P } \\
\text { H } \\
\text { P }\end{array}$ & $\begin{array}{l}\text { Between groups } \\
\text { Within groups } \\
\text { Total }\end{array}$ & $\begin{array}{l}0.0002 \\
0.0200 \\
0.0202\end{array}$ & $\begin{array}{c}2 \\
76 \\
78\end{array}$ & $\begin{array}{l}0.0003 \\
0.0003 \\
0.0003\end{array}$ & $\begin{array}{l}0.3923 \\
0.6773 \\
0.7498 \\
0.6873\end{array}$ \\
\hline M4 & Test & & & SS & df & MS & \\
\hline & Kruskal-Wallis & $\begin{array}{l}\text { Sources } \\
\text { F } \\
\text { P } \\
\text { H } \\
\text { P }\end{array}$ & $\begin{array}{l}\text { Between groups } \\
\text { Within groups } \\
\text { Total }\end{array}$ & $\begin{array}{l}0.0004 \\
0.0069 \\
0.0073\end{array}$ & 2 & & $\begin{array}{l}2.4013 \\
0.0974 \\
3.9857 \\
0.1363\end{array}$ \\
\hline
\end{tabular}

SS, sum of squares; df, degrees of freedom; MS, mean squares; F, value of Fisher's statistics; H, value of H statistics; P, value of probability associated to each test. 
change in the glycan/molecular composition of mucous layer of the skin which can be related to the high mortality rates. However, the $O$. vulgaris paralarvae used in this study showed a growth pattern in line with the data reported in previously studies ${ }^{8}$ (the body length ranged from $1.7 \pm 0.4 \mathrm{~mm}$ to $3.1 \pm 0.5 \mathrm{~mm}$ at four days and twentyeight days from hatchling, respectively) and they exhibited the same morphological features described on wild animals ${ }^{23}$ with no signs of anatomical damage.

The mantle surface exhibited neutral glycan and acidic non-sulphated glycans (PAS and AB 2.5 positivity) as well as glycoproteins terminating with Gal $\beta 1,3$ GalNAc (PNA), Gal $\beta 1,4 \mathrm{GlcNAc}$ (RCA I) and fucose linked $\alpha 1,6$ to GlcNAc or $\alpha 1,3$ to $\mathrm{N}$-acetyllactosamine (AAA). This suggests that both $\mathrm{m} 1$ and $\mathrm{m} 2$ cells participate in the production of mucus layering the mantle surface. In sepioids the epidermal mucus layer has been related to the sticking of the sand for camouflage ${ }^{19}$ as well as in the reduction of friction during swimming. ${ }^{21}$ Since in $O$. vulgaris the relative importance of lubrication in swimming and adhesive interactions with the substrate probably change from a planktonic to a bottomdwelling life style, we could hypothesize that the variation in abundance of $\mathrm{ml}$ and $\mathrm{m} 2$ cells observed from early to older posthatchlings could significantly affect these ecological requirements.

The arms exhibited suckers consisting of the infundibulum and acetabulum chambers which were connected through a constricted orifice. The epithelium lining the infundibulum consisted of cuboidal cells, whereas that covering the acetabulum was squamous. These features differ from those observed in the sucker of adult individuals. Kier and $\mathrm{Smith}^{20}$ reported that the infundibulum is lined with a tall columnar epithelium and the acetabulum with a simple cuboidal one. This feature, along with the absence of the circumferential marginal fold surrounding the infundibulum in suckers of adult individuals observed in previous studies, ${ }^{6}$ suggests that the suction process in hatchling octopus paralarvae is not as effective as in adults.

Morphological studies on O. vulgaris paralarve suckers are scarce ${ }^{23,52}$ and reports on the molecular composition of these structure are lacking. Kier and Smith ${ }^{20}$ detected epithelial cells containing acidic mucopolysaccharides in a zone surrounding the sucker rim of adult $O$. joubini, but they did not describe typical mucus-secreting cells. In this study, we observed for the first time the presence of two mucous cells, defined as $\mathrm{m} 3$ and $\mathrm{m} 4$ cells, whose relative abundance did not significantly change during the investigated period. The $\mathrm{m} 3$ cells were scattered in the epithelium surrounding the infundibulum. This cell type contained neutral as well as acidic non-sulphated mucins constituted by mannosylated (Nlinked) glycans (Con A affinity) containing GlcNAc (WGA reactivity) and terminating with lactosamine (RCA I staining) as well as with fucosylated residues binding AAA. $\mathrm{m} 4$ cells expressed neutral as well as acidic sulphated and non-sulphated mucins constituted of oligosaccharides containing GlcNAc (WGA affinity), sialic acid (SNA binding), and AAA-binding fucose.

The detected glycoproteins could be involved in the constitution of mucus surrounding the sucker rim to improve the watertight seal during the adhesion process. However, their differential composition suggests a different role of $\mathrm{m} 3$ - and $\mathrm{m} 4$ secreted glycoproteins in this process. Moreover, the release of sulphated glycoproteins on the surface of the aquatic animal epidermis has been related to lubrication that is necessary in protecting the body against mechanical damages as well as in increasing of the viscosity to trap bacteria and other pathogens (reviewed by Rai et $\left.a l .{ }^{53}\right)$. Interestingly, the morphometric analysis revealed that the number of $\mathrm{m} 3 \mathrm{e}$ $\mathrm{m} 4$ cells is constant during the first month of life after hatching. This suggests that these cells, on the contrary of $\mathrm{m} 1$ and $\mathrm{m} 2$ cells, are not affected by the rearing conditions.

As for the sucker surface, the infundibulum surface was lined with the cuticle containing neutral and sulphated mucins which were constituted of GlcNAc, Galß1,3GalNAc, lactosamine, and all investigated fucosylated glycans. Interestingly, the cuticle covering the acetabulum expressed a different glycan pattern compared to the infundibulum, since it lacked acidic glycans and expressed highly mannosylated glycans and $\alpha 1,2$-linked fucose. This finding agrees with the report that the sucker is covered by a chitinous cuticle which is particularly well developed on the infundibulum. ${ }^{20}$ On this basis, we suppose that the differential glycan composition of infundibulum and acetabulum cuticle may differently aid the suckers in attaining suction adhesion. Different functions of the two compartments of the sucker have been reported in previous studies by different technical approaches. ${ }^{54,55}$ The adhesive properties of mucus have been observed in other mollusks. Glue mucus in gastropodes is more rich in sulphated and acetylated sugars than trail mucus. ${ }^{18,56,57}$

In conclusion, the present study provides for the first time an insight into the glycoconjugates expressed in the secretory cells and the surface lining the mantle and the suckers of reared $O$. vulgaris paralarvae. In addition, the results provide information on the changes in the number of mucous cells scattered along the mantle of skin of $O$. vulgaris paralarvae during the first month of life. The presented results add information which could be useful in sustain pure as well aquaculture experimental researches aimed to better understand the physiology of this species during this critical stage of the life cycle.
Table 6. Results of Tukey's Honestly-Significant-Difference (THSD) and Dwass-SteelChritchlow-Fligner (DSCF) post-hoc tests for comparisons of means between M1 and M2 numbers of mucous cells per $100 \mu \mathrm{m}$ of the Octopus vulgaris paralarvae mantle skin.

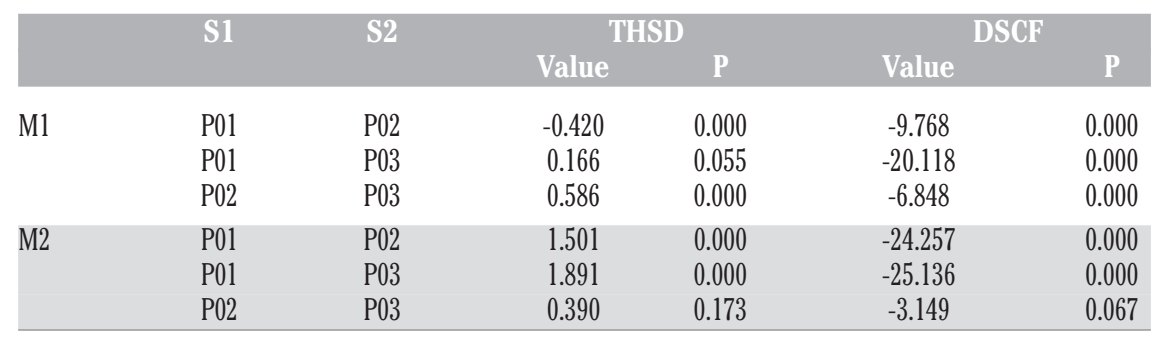

S1-3, sample; P, value of probability associated to each test.

\section{References}

1. Iglesias J, Sánchez FJ, Bersano J, Carrasco JF, Dhont J, Fuentes L, Linares F, Muñoz JL, Okumura S, Roo J. Rearing of Octopus vulgaris paralarvae: present status, bottlenecks and trends. Aquaculture 2007;266:1-15.

2. Young RE, Harman RF. Larva, paralarva and subadult in cephalopod terminology. Malacologia 1988;29:201-7.

3. O'dor R, Mangold K, Boucher-Rodoni R, Wells M, Wells J. Nutrient absorption, storage and remobilization in Octopus vulgaris. Mar Freshwater 
Behav Physiol 1984;11:239-58.

4. Hanlon RT, Wolterding MR. Behavior, body patterning, growth and life history of Octopus briareus cultured in the laboratory. Am Malacol Bull 1989;7:21-45.

5. Boletzky SV. Biology of early life stages in cephalopod molluscs. Adv Mar Biol 2003;44:143-203.

6. Villanueva R, Norman MD. Biology of the planktonic stages of benthic octopuses. Oceanogr Mar Biol Ann Rev 2008;46:105-202.

7. Villanueva R, Nozais C, Boletzky Sv. Swimming behaviour and food searching in planktonic Octopus vulgaris Cuvier from hatching to settlement. J Exp Mar Biol Ecol 1997;208:169-84.

8. Carrasco JF, Arronte JC, Rodríguez C. Paralarval rearing of the common octopus, Octopus vulgaris (Cuvier). Aquac Res 2006;37:1601-5.

9. Hormiga JA, Almansa E, Sykes AV, Torres NV. Model based optimization of feeding regimens in aquaculture: Application to the improvement of Octopus vulgaris viability in captivity. $\mathrm{J}$ Biotechnol 2010;149:209-14.

10. Packard A. The skin of cephalopods (coleoids): general and special adaptations. In: Trueman E, Clarke M, editors. The Mollusca. Form and Function. San Diego: Academic Press; 1988. p. 37-67.

11. Roper CF, Lu C. Comparative morphology and function of dermal structures in oceanic squids (Cephalopoda). Washington, D.C.: Smithsonian Institution Press; 1990.

12. Shephard KL. Functions for fish mucus. Rev Fish Biol Fisher 1994;4:401-29.

13. Diaz AO, Garcia AM, Devincenti CV, Goldemberg AL. Mucous cells in Micropogonias furnieri gills: histochemistry and ultrastructure. Anat Histol Embryol 2001;30:135-9.

14. Raj VS, Fournier G, Rakus K, Ronsmans M, Ouyang P, Michel B, et al. Skin mucus of Cyprinus carpio inhibits cyprinid herpesvirus 3 binding to epidermal cells. Vet Res. 2011;42:92.

15. Smith AM. The structure and function of adhesive gels from invertebrates. Integr Comp Biol 2002;42:1164-71.

16. Smith AM. Gastropod secretory glands and adhesive gels. In: Byern J, Grunwald I, editors. Biological Adhesive Systems: Springer Vienna; 2010. p. 41-51.

17. Gutternigg M, Burgmayr S, Poltl G, Rudolf J, Staudacher E. Neutral N-glycan patterns of the gastropods Limax maximus, Cepaea hortensis, Planorbarius corneus, Arianta arbustorum and Achatina fulica. Glycoconj J.
2007;24:475-89.

18. Davies MS, Hawkins SJ. Mucus from marine molluscs. Adv Mar Biol. 1998; 34:1-71.

19. Singley C. Histochemistry and finestructure of the ectodermal epithelium of the sepiolid squid Euprymna scolopes. Malacologia. 1982;23:177-92.

20. Kier WM, Smith AM. The structure and adhesive mechanism of octopus suckers. Integr Comp Biol. 2002;42:114653.

21. Lee DG, Park MW, Kim BH, Kim H, Jeon MA, Lee JS. Microanatomy and ultrastructure of outer mantle epidermis of the cuttlefish, Sepia esculenta (Cephalopoda: Sepiidae). Micron. 2014;58:38-46.

22. Brocco S, O'Clair R, Cloney R. Cephalopod integument: The ultrastructure of Kölliker's organs and their relationship to setae. Cell Tiss Res. 1974;151:293-308.

23. Nixon M, Mangold K. The early life of Octopus vulgaris (Cephalopoda: Octopodidae) in the plankton and at settlement: a change in lifestyle. J Zool 1996;239:301-27.

24. Moxica C, Otero J, Iglesias J, Sánchez F. Comportamiento reproductor, puestas y desarrollo embrionario del pulpo Octopus vulgaris (Cuvier, 1797) en cautividad. Monogr Inst Canar Ci Mar 2001;4:549-54.

25. Mc Manus J. Histological and histochemical uses of periodic acid. Stain Technol. 1948;23(3):99-108.

26. Steedman HF. Alcian blue 8GS: a new stain for mucin. Q J Microsc Sci. 1950;91:477-9.

27. Spicer SS. Diamine methods for differentialing mucosubstances histochemically. J Histochem Cytochem. 1965;13: 211-34.

28. Scillitani G, Mentino D, Liquori GE, Ferri D. Histochemical characterization of the mucins of the alimentary tract of the grass snake, Natrix natrix (Colubridae). Tiss Cell. 2012;44:28895.

29. Gallagher JT, Morris A, Dexter TM. Identification of two binding sites for wheat-germ agglutinin on polylactosamine-type oligosaccharides. Biochem J. 1985;231:115-22.

30. Lyer PN, Wilkinson KD, Goldstein LJ. An -N-acetyl-D-glycosamine binding lectin from Bandeiraea simplicifolia seeds. Arch Biochem Biophys 1976; 177:330-3.

31. Shibuya N, Goldstein IJ, Broekaert WF, Nsimba-Lubaki M, Peeters B, Peumans WJ. The elderberry (Sambucus nigra
L.) bark lectin recognizes the Neu5Ac(alpha 2-6)Gal/GalNAc sequence. J Biol Chem. 1987;262:1596601.

32. Lotan R, Sharon N. Peanut (Arachis hypogaea) agglutinin. Methods Enzymol. 1978;50:361-7.

33. Baenziger JU, Fiete D. Structural determinants of Ricinus communis agglutinin and toxin specificity for oligosaccharides. J Biol Chem. 1979;254:9795-9.

34. Bhattacharyya L, Haraldsson M, Brewer CF. Precipitation of galactosespecific lectins by complex-type oligosaccharides and glycopeptides: studies with lectins from Ricinus communis (agglutinin I), Erythrina indica, Erythrina arborescens, Abrus precatorius (agglutinin), and Glycine max (soybean). Biochemistry. 1988;27:1034-41.

35. Finne J, Krusius T. Preparation and fractionation of glycopeptides. Methods Enzymol. 1982;83:269-77.

36. Debray H, Montreuil J. Aleuria aurantia agglutinin. A new isolation procedure and further study of its specificity towards various glycopeptides and oligosaccharides. Carbohydr Res 1989;185:15-26.

37. Sughii S, Kabat EA, Baer HH. Further immunochemical studies on the combining sites of Lotus tetragonolobus and Ulex europaeus I and II lectins. Carbohydr Res 1982;99:99-101.

38. Debray H, Decout D, Strecker G, Spik G, Montreuil J. Specificity of twelve lectins towards oligosaccharides and glycopeptides related to N-glycosylproteins. Eur J Biochem 1981;117:41-55.

39. Mentino D, Mastrodonato M, Rossi R, Scillitani G. Histochemical and structural characterization of egg extra-cellular matrix in bufonid toads, Bufo bufo and Bufotes balearicus: molecular diversity versus morphological uniformity. Microsc Res Tech. 2014;77:910-7.

40. Scillitani G, Moramarco AM, Rossi R, Mastrodonato M. Glycopattern analysis and structure of the egg extra-cellular matrix in the Apennine yellow-bellied toad, Bombina pachypus (Anura: Bombinatoridae). Folia Histochem Cytobiol 2011;49:306-16.

41. Rasband W. ImageJ. Bethesda, Maryland: US National Institutes of Health; 2016. Computer program. http://imagej.nih.gov/ij/

42. Zaiontz C. Real statistical analysis using Excel. 2015. Computer program. http://www.real-statistics.com/

43. Vidal EA, Haimovici M. Feeding and the possible role of the proboscis and mucus cover in the ingestion of 
microorganisms by rhynchoteuthion paralarvae (Cephalopoda: Ommastrephidae). Bull Mar Sci. 1998;63:30516.

44. Brockhausen I, Schachter H, Stanley P. O-GalNAc glycans. In: Varki A, Cummings RD, Esko JD, Freeze HH, Stanley P, Bertozzi CR, et al., editors. Essentials of Glycobiology. Cold Spring Harbor, NY: Cold Spring Harbor Laboratory Press; 2009. p. 115-28.

45. Menghi G, Ottaviani E, Accili D, Bolognani Fantin AM. Identification of muramyl derivatives in Mollusca Gastropoda tissue. Histochemistry. 1991;96:209-13.

46. Stanley P, Schachter H, Taniguchi N. NGlycans. In: Varki A, Cummings RD, Esko JD, Freeze HH, Stanley P, Bertozzi CR, et al., editors. Essentials of Glycobiology. Cold Spring Harbor, NY: Cold Spring Harbor Laboratory Press; 2009. p. 101-14.

47. Schauer R. Sialic acids as regulators of molecular and cellular interactions. Curr Opin Struct Biol;19:507-14.

48. Mandal C, Schwartz-Albiez R, Vlasak
R. Functions and Biosynthesis of OAcetylated Sialic Acids. Top Curr Chem 2015;366:1-30.

49. Petraccioli A, Maio N, Guarino FM, Scillitani G. Seasonal variation in glycoconjugates of the pedal glandular system of the rayed Mediterranean limpet, Patella caerulea (Gastropoda: Patellidae). Zoology 2013;116:186-96.

50. Varki A, Schauer R. Sialic Acids. In: Varki A, Cummings RD, Esko JD, Freeze HH, Stanley P, Bertozzi CR, et al., editors. Essentials of Glycobiology. 2010/03/20 ed. Cold Spring Harbor, NY: Cold Spring Harbor Laboratory Press; 2009. p. 199-217.

51. Lenz S. Histologische und elektronenmikroskopische Untersuchungen am Integument des paralarvalen und adulten Octopus vulgaris Cuvier, 1797. PhD Thesis., University of Münster, 1998, 1998.

52. Schmidtberg H. Ultrastructural studies of the suckers of newly hatched Eledone moschata and Octopus vulgaris (Mollusca; Cephalopoda). In: Olóriz F, Rodríguez-Tovar F, editors. Avancing research on living and fossil cephalopods: Springer US; 1999. p. 203-21.

53. Rai AK, Srivastava N, Kumari U, Mittal S, Mittal AK. Histochemical analysis of glycoproteins in the secretory cells in the epidermis of the head skin of Indian Major Carp, Labeo rohita. Tiss Cell 2012;44:409-17.

54. Kier WM, Smith AM. The morphology and mechanics of Octopus suckers. Biol Bull 1990;178:126-36.

55. Tramacere F, Beccai L, Kuba M, Gozzi A, Bifone A, Mazzolai B. The morphology and adhesion mechanism of Octopus vulgaris suckers. PLoS One 2013;8:e65074.

56. Pawlicki JM, Pease LB, Pierce CM, Startz TP, Zhang Y, Smith AM. The effect of molluscan glue proteins on gel mechanics. J Exp Biol 2004;207(Pt 7): 1127-35.

57. Smith AM, Morin MC. Biochemical differences between trail mucus and adhesive mucus from marsh periwinkle snails. Biol Bull 2002;203:338-46. 